\section{The Impact of the US Financial Crisis on How Students Pay for College}

\section{Arthur M. Hauptiman}

Arthur M. Hauptman is an independent public-policy consultant specializing in higher education finance issues. He is based in Arlington, Virginia. Email:art.hauptman@yahoo.com.

$\mathrm{T}_{\mathrm{w}}^{\mathrm{h}}$ he recent failure of several major financial institutions, widespread credit squeeze, and big drop in stock prices have led to what is considered by many as the worst financial situation in the United States since the Great Depression in the I930s. This crisis has had or will have major impacts on most sectors of the US economy-including higher education, which now accounts for roughly 3 percent of the US gross domestic product. While this article views American issues, the global impact of the financial difficulties in the United States means that many countries around the world may face similar challenges in charting the course of their economies and in financing their higher education systems.

The impact on the ability of students and their families to pay for college will likely extend, including whether many families can still use home equities to pay for college and how the downturn in the stock market affects the growing dependence on family savings for tuition and other expenses.

Most comments about the effects of this financial crisis on higher education have focused on the possible drying up of student loans. However, the impact on the ability of students and their families to pay for college will likely extend, including whether many families can still use home equities to pay for college and how the downturn in the stock market affects the growing dependence on family savings for tuition and other expenses. The financial crisis will also involve large ramifications for many aspects of institutional finance such as whether endowments and gifts continue to grow as they have in the recent past, as well as how colleges and universities price themselves.

Complicating this discussion is the lack of comprehensive or reliable data on the effects of the current financial squeeze on any of these resources for higher education. But each of these plausible effects is worth investigating and policymakers ought to consider how to deal with them.

\section{StUdent LoAns}

Three basic kinds of student loans now exist in the United States-two of them created in federal legislation. The largest source of student borrowing in the United States is the federally guaranteed program first established in 1965 . The private lenders are insured against most losses via federal and state guarantee arrangements; these loans account for more than half of all student loans in the United States, which now amount to nearly \$Ioo billion annually.

In the I990s, the federal government created a direct-loan program working directly with institutions to provide loans to students. Although this federal program now represents less than one-fifth of all student borrowing, it has introduced competition into the marketplace as private lenders and servicers can no longer threaten to vacate the student-loan field if their legislative demands and needs are not met.

Private student loans will be most affected, as the credit crunch will most likely impact nonguaranteed and nonsubsidized loans.

Private loans without federal involvement or guarantee have been the fastest-growing component of the student-loan market in the United States in recent years, for they have been used to make up for the difference in what colleges charge and what aid is available from various sources, including federally based loans. These private loans have mushroomed over the past decade to account for 20 percent or more of the total student borrowing.

Based on statistics provided for the 2007/08 academic year, the current financial crisis seems to have had thus far a relatively modest impact. The federal student loan volume grew by about Io percent between 2006/07 and 2007/08. By contrast, private loans reached a plateau, and volume stayed fairly level. This status reflects the fact that most students and parents had made their borrowing arrangements for the current academic year before the worst of the crisis hit.

In the 2008/09 academic year, student borrowing will likely be affected by recent events in the financial markets. Clearly, private student loans will be most affected, as the credit crunch will most likely impact nonguaranteed and nonsubsidized loans. Private nonguaranteed lending may drop by half or more over the upcoming year as previously available sources of capital will dry up and disappear. The effect of this drop-off will be most pronounced for students in higher-priced private institutions and for-profit trade schools, where in recent years a growing number of students and parents have come to rely on private loans to make up the difference in federal loan limits and the higher prices charged at these institutions. At private, nonprofit institutions, tuition and fees now average \$25,000 per year, and total costs of attendance including charges for housing and meals average nearly $\$ 35,000$. Annual costs at 
for-profit trade schools-on average, $\$ 13,000$ in 2008/09are less than at private nonprofit institutions but still twice as much as the tuition and fees charged at public four-year colleges and universities, which average $\$ 6,600$ in 2008/09.

By contrast, federally guaranteed loans and direct-loan volume have only marginally been affected by recent events. In fact, Congress this year took steps to ensure the continued availability of federal capital so that students could be assured that loans will be available next year and the following year.

\section{Home-Equity Lines of CRedit}

With the rapid increase in tuition over the past quarter century and the even more rapid growth in housing prices over the past decade, lines of credit based on the value of a family's home equity have become an increasingly popular way for many American parents to pay for college. Under this arrange-

The next year or two will be marked by re-evaluations of how family savings will be used in the future to pay for college.

ment, parents can borrow against the portion of the value of their home that exceeds what they owe on it. Also, those using home equity lines of credit qualify to take tax deductions on the interest they pay on these lines of credit under current tax rules. Although precise data are not available, a reasonable estimate is that this form of finance provides perhaps \$io billion dollars in loans used to help pay expenses related to higher education.

But the current financial crisis is likely to put a real squeeze on this popular source of student finances. Many banks are simply reluctant to lend in a market where the value of houses-the collateral for these loans-has dropped sharply, making this form of financing much more problematic. It is reasonable to assume that the amount available through this source to help parents pay for college also will drop sharply in coming years, at least by one-quarter and perhaps by as much as half.

\section{Drawing on Savings}

Because of the high and growing prices for higher education in the United States, parents increasingly realize they must save while their children are young in order to pay for at least some of their college costs. This saving takes many forms including investing directly in stocks and bonds and through participation in mutual funds, retirement accounts, and pension funds. The use of savings for college in the United States has further expanded through the enactment of a series of provisions that extend tax benefits for savings allocated into designated college savings accounts. But the recent loss in stock market values of more than one-third from previous highs could have a huge negative impact on the ability of many parents to pay the high prices of college in the United States.

As in the case of home equity lines of credit, the amount of savings used to pay for college has expanded sharply in recent decades. The next year or two will be marked by re-evaluations of how family savings will be used in the future to pay for college. A reasonable surmise is that the changing financial situation will have a greater impact on where students go to school than whether they continue their educational career at the postsecondary level. Thus, parents may be more likely to tighten their belts and ask or require their children to attend public institutions located in state where tuition and fee levels are one-fourth of what private colleges charge. Again the effect is likely to be most evident in the admissions process for the 2009/10 academic year as students and their families make plans for next year.

In sum, the financial crisis could affect the plans and decisions of hundreds of thousands if not millions of current and prospective students in the United States, regarding whether and where they enroll in postsecondary education. The institutions most likely to be affected are those in the private sector because of the higher prices they tend to charge, but enrollments in all types of institutions will be affected by recent financial events here in the United States. It would not be surprising to discover similar if perhaps milder effects in many other countries experiencing the effect of worldwide financial difficulties.

\section{Arab Open and Virtual Universities David Porcaro}

David Porcaro is a doctoral student in instructional technology at the University of Georgia. E-mail: dporcaro@uga.edu.

The value of open and virtual universities in the Middle East 1 and North Africa can be measured through their recent explosive growth. In the eight years since André Elias Mazawi called for the establishment of the Arab Open University in the Winter 2000 International Higher Education, several Middle Eastern universities have opened their virtual doors.

\section{Regional Universities}

The Arab Open University (www.arabou.org), a UNESCOsponsored institution established in 2002, is the most widespread Arab-language open university. Headquartered in Kuwait, with degree-granting branches in Bahrain, Egypt, Jordan, Kuwait, Lebanon, Saudi Arabia, and Oman, in 2003/04 Arab Open University enrolled nearly I7,000 stu- 